\section{Exploring Literacy Initiatives}

\section{Jennifer Cassidy, Amanda Dreyer, Julia Johnson, Heidi Lenz, Veronica Manning, Kelly Nolan, Amelia O'Seasnain, Emily Phillips, and Diana Spence}

$\mathrm{L}$ iteracy is more than reading and writing. It is about how we communicate and survive in society. It is about social practices, relationships, knowledge, language and culture. Research suggests that often those who are gifted with "literacy" may take these skills for granted - but those who are less fortunate and perhaps even excluded from education and training may often be deprived of human rights, discriminated against and unable to maximize opportunities. Our survey of literacy initiatives demonstrates clearly that those who are less literate seem to best appreciate the notion of 'literacy as freedom'.

Global literacy issues have captured the attention of many world organizations. Mandates and mission statements include proactive initiatives to encourage and increase global literacy. What follows is a small sampling of the many organizations that have developed programs designed to contribute to the improvement of literacy across a broad base of intervention access points. While the information herein is representative it is by no means an exhaustive survey. There are literally thousands of organizations that sponsor Web sites with valuable information about literacy programs and initiatives. We offer a brief overview of international, national and local school proactive interventions designed to encourage and enhance literacy in schools and communities. School boards that represent membership in the Brock-Golden Horseshoe Education Consortium are also highlighted. We have included a list of WEB sites for teachers and parents interested in obtaining more information about literacy initiatives.

\section{Global Initiatives}

The United Nations Educational, Scientific and Cultural Organization, (UNESCO) has declared 2003-2012 as United Nations Literacy Decade. This campaign was designed by the United Nations General Assembly to encourage and to expand access to literacy worldwide. According to research more than 861 million adults are lacking access to literacy and over 113 million children are not attending school, thereby functionally unable to attain means of becoming literate. The mandate of UNESCO's decade for literacy movement is to encourage children and adults to learn to read, write and communicate by reaching out to the poorest and most disadvantaged nations and communities. Their mission statement "literacy for all, a voice for all, learning for all" serves as a beacon for literacy initiatives around the world.

Better World Books is a self-sustaining business which promotes literacy programs in underprivi-

\section{Better World Books}

leged countries. Using profits raised by selling donated used books, this organization institutes and supports literacy programs led by non-profit organizations in Africa and South East Asia. As well, they send many used books to these continents to be used as resources with the programs. In 2004 alone, they shipped 200,000 books to the African continent.

\section{Room to Read}

The goal of Room to Read is to establish locales that will house literacy programs. They aid communities by paying a portion of the building expenses, but require that they raise a significant portion themselves (often through seeking donations). This allows the organization to reach many more communities, and instills a sense of accomplishment in the citizens they serve. Since its millennium development, hundreds of schools and thousands of libraries have been built in developing nations. Room to Read has shipped supplies, including books and computers, and has offered almost one thousand scholarships to students in African countries.

\section{World Computer Literacy}

NIIT technologies decided many years ago to increase the availability of computers and technologies to developing nations ill equipped and hard pressed to purchase expensive infra structure, hardware and software. The World Computer Literacy Day Mission, established in 2001, is one of the most wide-spread literacy initiatives across the globe. In its first year, 104,000 citizens learned to operate and manipulate computers. Over 400,000 individuals have been impacted by this mission today. The World Computer Literacy Mission has spread to far ends of the globe, assisting many countries in Africa 
and Asia expanding access and to technology ad making training and education a priority. It is hoped that through increased technological involvement economical, social, and cultural barriers will decline.

\section{World Literacy of Canada}

The World Literacy of Canada focuses attention primarily on adult literacy. Its primary intervention addresses women's literacy issues. Centered primarily in South Asia and Canada they promote programs in cultural and societal contexts that best integrate and encourage the development of literacy within the community.

\section{Grassroots.org}

The purpose of Grassroots.org is not only to increase literacy in the world population, but to educate with a purpose. Their mission is clearly stated, "every ailment in the world can be lessened if educated people commit themselves to the task". This organization posits that many of the issues and problems faced in the global community are a direct result of a lack of education. They argue that through literacy initiatives many diseases could be avoided or diminished.

These and other highly visible and important organizations, such as the International Reading Association and Scholar's Choice place literacy initiatives at the forefront of their programs, and are doing so with a high success rate. Their efforts have helped and continue to help increase literacy initiatives on a global scale. Their initiatives are particularly commendable because they are often charitable and give aid and instruction to less equipped countries.

We urge you to visit their web sites.

\section{Canada: Provinces}

Ministries and Departments of Education across Canada are actively working to promote literacy in public schools. Their websites reveal various current programs and initiatives.

Last year, the British Columbia Ministry of Education announced a series of literacy initiatives such as a website for teachers and parents as well as books and resources for students attending kindergarten and grade one. The primary goal is to help children gain the reading, writing and math skills they require to succeed at school. The province has invested 23.4 million dollars to improve library services and, in 2005, 60 school districts will share five million dollars in the province's first-ever program supporting innovative literacy projects across BC.

Through a joint project with the federal government's National Literacy Secretariat (NLS), Alberta is piloting and evaluating a family literacy model in selected regions of the province. The government uses other programs such as the Early Literacy Initiative, institutional and community-based adult literacy programs and family literacy projects. For 2004-05, a new funding model was developed for private schools to hire more classroom support or to purchase resource materials designed to assist students in grades one and two with "difficulties in developing reading readiness and early literacy skills". This model is a continuation of the 2001 model for public schools.

Regional colleges and other community-based organizations in Saskatchewan provide parttime literacy development programs to adults who wish to improve their literacy skills. The Saskatchewan Literacy Network promotes literacy throughout the province and maintains a website that is a great resource for parents and teachers seeking literacy programs. Currently, the NLS is accepting proposals for Adult Literacy Project Funding: Saskatchewan for the year 2005-06.

Adult Learning and Literacy (ALL) provides grants to Manitoba adult learning centres and part-time community-based literacy programs. As well they support the development and delivery of adult focused programming. ALL also offers training and professional development workshops for new and experienced literacy practitioners and adult learning centre teachers. There is currently a call for proposals for 2005-06 for Adult Literacy Projects in Manitoba.

The Ontario government strongly believes in improving student literacy. The slogan "literacy is the foundation for success in school and life" spearheads many initiatives. The provincial Literacy and Numeracy Secretariat emphasizes literacy-centered education, particularly in the primary grades. Recently, the Ontario government released several resources for teachers and parents including Think Literacy: CrossCurricular Approaches Grades 7-12, and a more recent document to assist older students.

As of January 2005, the government started a new focus, centering on the need to improve boys' literacy skills, using role models like Mike Clemens of the Toronto Argonauts. Recently a resource was distributed to all schools titled Me Read? No Way! A Practical Guide to Improving Boys' Literacy Skills.

Québec's Education minister recently announced a three-year action plan to promote reading. More than 60 million dollars will 
revitalize school libraries. Included in the plan are competitions, supports for school and library personnel, and a variety of literary training camps for teachers. Several symposiums aimed at the entire education system are planned. A government appointed spokesperson for reading has been given a mandate to implement the action plan. Reading for enjoyment is an underlying theme of the initiative that will specifically target boys.

"Quality Schools, High Results" is a "strategic plan," developed and implemented by the New Brunswick's "Quality Learning Agenda," It is specifically aimed at improving student achievement by targeting early literacy. Specific interventions are designed to guarantee that every student attains a suitable reading level by the end of grade two. Initiatives to meet this goal include communication of grade two reading standards to parents, early identification (through assessments) of struggling readers and interventions to meet their needs, public library cards for students, daily reading time, new books, and "literacy enhancement and tutoring programs" for students. Hiring of "early literacy specialists" and provision of training for teachers are other important measures towards meeting the plan's objectives.

"Learning for Life - Planning for Student Success" is a major initiative of Nova Scotia's Department of Education. Its' mandate is to improve public education through programs such as "Reading Recovery," "Math Matters," and "Active Readers." "Active Readers" is a literacy project that has purchased thousands of new books and provided resources for students and teachers including professional development. A website has been developed to assist teachers and parents who are interested in encouraging literacy initiatives. The program began in 2000 involves primary and elementary students as well as grade nine secondary students.

Two main organizations have joined forces in Prince Edward Island to improve adult literacy. It is recorded that more than $40 \%$ of the adult population exhibit underdeveloped literacy skills. The Literacy Initiatives Secretariat has created many projects including Literacy/Adult Basic Education Initiative, Family Literacy and a Workplace Education PEI Literacy. The PEI Literacy Alliance is responsible for over 50 literacy programs across the island.

Newfoundland \& Labrador's Department of Education provides an extensive literacy campaign. "Words to Live By: A Strategic Literacy Plan for Newfoundland and Labrador," was published in 2000. A "Literacy office" has been established to oversee the implantation of the various initiatives. In addition to reading and writing, numerous literacy programs are offered in many regions of the province. Specific objectives of the governments' plan include promoting literacy among young children, $\mathrm{K}-12$ students, and adults, as well as increasing pubic sensitivity to literacy.

The Yukon government has adopted a plan to implement strategies designed to develop necessary skills in using information and basic technology for daily life for northerners. In its 2001 Literacy Policy Statement the Department of Education outlines various plans "to provide maximum opportunity for all Yukon people to acquire the necessary literacy skills to be successful in their community, work and personal life".

The Department of Education seeks to enhance literacy, numer- acy, computing and problem solving in one or more of the Northwest Territories' official languages. Proactive initiatives target adults interested in learning the skills necessary to survive and compete in society. The Department of Education is concerned that many of its citizens lack the necessary foundations of education to "access further education and employment." Therefore in conjunction with the NWT Literacy Council they have published a document dedicated to assisting students with their reading and writing skills. They are also promoting strategies to increase competencies in aboriginal languages.

The Nunavit Department of Education outlines two specific initiatives on literacy. First, their focus is funding capital resources for developing better libraries, more able to address the needs of the local population. Second, there is a mandate in the territory to improve Inuktitut literacy. The Arviat District Education Authority's website promotes the development of literacy in this language as well as improving the use of syllabics with a focus on the every day needs of the local populations.

While each province and territory coordinates its own literacy initiatives, several common themes appear across the country. The need to improve libraries and support classrooms through the purchase of more resources is a main thrust. Moreover, the targeted groups are young school-aged children and adult learners. In the territories, there is a focus on developing native languages; while in Québec and Ontario, efforts concentrate on boys' literacy skills. In most cases, the Departments of Education work with the NLS as well as provincial literacy councils. 


\section{Consortium Partners}

School boards of the BrockGolden Horseshoe Educational Consortium have similar policies designed to enhance and encourage literacy. Most define literacy as basic reading and writing skills. Some expand this definition to encompass oral communication, computer and media literacy, life skills, financial literacy, justice, health and coping skills. The Ontario Government and the Ontario Ministry of Education recently implemented literacy and numeracy standards. The provincial testing of grade nine student literacy skills - the Ontario Secondary School Literacy Test (OSSLT) - has prompted school administrators to encourage and promote literacy initiatives. Boards surveyed believe that the results of these tests are essential in assessing the success of the transfer of literacy skills to students. All of the school boards have literacy consultants at the elementary and secondary levels working to develop and assess programs designed to improve literacy and numeracy. Boards hired literacy teachers to provide system wide support for teachers providing assistance where it is best needed. School boards have sought feedback from students, parents, teachers, and community members in order to determine the effectiveness of their initiatives and find out where improvement is required. The emphasis placed on at-risk students is significant. A variety of remedial and enrichment programs provide help to struggling students. Several schools offer after-school homework and home study assistance through on line support groups. The Brant Haldimand Norfolk Catholic District School Board identifies their schools with the highest needs and assigns their six literacy teachers to work half days in schools on a rota- tional basis. Several boards interviewed have implemented sophisticated tracking programs to compile and analyze research to ensure efficacy of the programs offered.

Professional development workshops, literacy short - courses, consultancy interventions and resources manuals are constantly reviewed and updated. The boards surveyed provide opportunities for small groups of elementary and secondary teachers to meet and discuss best practices. At these meetings school and department goals are revised and redeveloped. The Dufferin-Peel Catholic District School Board, as do others, offer summer literacy and mathematics courses for teachers and administrators. The Ontario Ministry's Think Literacy document published in 2003 has become a central resource for intermediate and senior level teachers. All the boards sponsor some kind of annual literacy conference for parents and teachers. For instance, "Make a difference in literacy and beyond - practical ways parents can boost learning" is the theme for this year's conference by the Peel District School Board; "Celebrate Literacy" is the District School Board of Niagara's initiative. The Halton Roman Catholic Separate District School Board sponsors an annual one day conference for parents and teachers. The Niagara Catholic District School Board will soon add a "literacy tool kit" to their website to facilitate independent learning and parental involvement. The Halton District School Board in cooperation with the Halton Literacy Advisory Board offers the Cozy Reading Program and sponsors a one day symposium for parents and teachers. Victoria Poe of 2 Lead Change provides an "at-risk youth employment program involving co-op" for students of varying literacy levels.
Boards provide extensive resources on their websites. Collectively school boards of the Brock-Golden Horsehoe consortium work hard to create a literate society that is able to communicate effectively.

\section{Web Sites}

There exist literally thousands of web sites devoted to encouraging literacy in schools and communities. Below are listed a number of different web sites that teachers may consult when looking for resources on literacy. They are easy to use and applicable to all disciplines and grade levels. They are presented in four categories: information on literacy, primary resources, elementary and secondary resources, and literacy in a second language environment. Be sure to visit the Canadian Education Association site and the Literacy Alberta site. Both organizations kindly permitted this journal to reprint information. The International Reading Association site provides important information about International Literacy day events and the Guidance Channel Online provides excellent links to resources and other sites. ERIC clearinghouse is an excellent resource as is Cyberkids Online Magazine and Canada's SchoolNet.

http://www.projectread.ca/

Project Read is a literacy network in the Waterloo-Wellington region. It is a service that encourages the enhancement of literacy skills through various programs. On this website there is information about and suggestions pertaining to adult literacy, family literacy, and workplace literacy.

http://www.on.literacy.ca/literacy/aboutlit.htm

The About Literacy link on the Ontario Literacy Coalition's website offers information from various research studies com- 
pleted on literacy. Here, there are very interesting fact sheets on the importance of literacy, literacy and health, family literacy, literacy and poverty, and workforce literacy.

www.readingonline.org

Reading Online is a peer-reviewed journal guided by an editorial council. In the summary section, this website states that it is the "leading online source of information for the world-wide literacy-education community" since its beginning in 1997. It focuses on a broad definition of literacy for children between the ages of 5 and 15 years old. The website contains various articles on literacy that are accessible to anyone. Anyone wishing to become a member of ROL will receive subscription to the journal and can select subscription to the book club. Members also receive discounts on a number of literacy resources.

http://www.scholastic.com/

The "teachers" section of this website has excellent graphic organizers for guiding reading as well as sample lesson plans and numerous teaching strategies related to literacy and reading. There are also online activities for students and teachers as well as resources specifically for kids, families, librarians, and administrators. The focus of these resources is mostly for primary and junior but there are some resources for intermediate and senior.

www.canteach.ca/elementary/ beginning10.html

This website is an excellent resource for elementary school teachers. It outlines some very specific ideas for centres promoting literacy. Each centre outlines the area of literacy on which it will focus: whether for reading, writing, listening, drawing, typing, and so on. The explanations of each centre are very simple. These centres could be set up throughout the classroom and be made available to the students any time during the day.

http://www.literacy.uconn.edu/ topics.htm

This website, sponsored by the University of Connecticut, contains a number of excellent links for all areas of literacy: best practices, early literacy, adolescent literacy, reading comprehension, content area literacy, multicultural literacy, comprehensive literacy, literacy standards, assessment in literacy, popular authors and children's literature, the connection between reading and writing, literacy and technology, and media literacy.

The section specifically for teachers breaks down the web resources into grade levels.

http://www.justreadnow.com /strategies/index.htm

Just Read Now is a project from the Beacon Learning Centre in Florida but this website contains a number of great reading strategies for discussion, active reading, vocabulary, and content organization. The Active Reading Strategies section offers ideas of how to use anticipation guides, response journals, and visual imagery just to name a few examples.

www.readwritethink.org/

The purpose of this website is to provide teachers and students with "the highest quality practices and resources in reading and language arts instruction". Just underneath the "highlight" section on the main page, there is a section called "literacy engagements". This section is divided into three different areas: learning language, learning about language, and learning through language. Each area contains a list of lesson plans ranging from kinder- garten to grade 12. The lesson plans are summarized on this first page and when a specific lesson is chosen, it gives an overview, a resource for the learning, the student objectives, and the instructional plan.

Literacy in a Second Language Environment

http://coe.sdsu.edu/people/ jmora/L2ReadingMMd

\section{/Default.htm}

This is a website created by Jill Kerper Mora (Ed.D) from San Diego State University. It discusses the complexity of literacy in a bilingual classroom. She addresses three orientations to reading instruction: the phonics approach, skills or balanced approach, and the whole language approach. In a colourful slideshow, the presentation offers insight on reading strategies in a second language.

http://wwww.itelslj.org/links

This website is designed for students and teachers of ESL. It covers a wide variety of resources for all areas of teaching and learning English as a Second Language. In the section under "teachers", one can find a link called "literacy". This link leads to other resources specifically for adult literacy.

\section{References}

Conference helps parents 'make a difference in literacy and beyond' http://www.peelschools.org/ parents/2005confintro.htm

EQAO results for Dufferin-Peel students above provincial averages http://www.dpcdsb.org/pr/ newsrelease/2004grade9mathresults. pdf

EQAO results show improvement for Dufferin-Peel students http://www.dpcdsb.org/pr/ newsrelease/2004EQAOresults.pdf

Halton District School Board releases Grade 10 literacy test scores http://www.hdsb.ca/news/ Release.asp?sMenuID=396\&sParent $\mathrm{ID}=63$ \&PageID $=4 \&$ news $\mathrm{ID}=303$ 
Literacy test pass rate up for Dufferin-Peel students

http://www.dpcdsb.org/pr/ newsrelease/eqaoliteracy2004.pdf

Today literacy remains a major global challenge,

http://portal.unesco.org/ education/en/ev.php

http://www.knowledgeispower.org

http://www.worldliteracy.com/do/ home

http:/ / www.betterworldboks.com/ wlp.aspx

www.bced.gov.ca/literacy

http://www.education.gov.ab.ca/ funding.FundingManual/pdf/ 3_5.pdf

http:www.sasked.gov.sk.ca/branches/ programs/literacy.shtml

http://www.edu.gov.mb.ca/aet/all/ index.html

http://www.edu.gov.on.ca/eng/ literacrynumeracy/index.html

http://www.meq.gov.qc.ca/MINISTRE /minis2005/a05114 and 501114

http://www.gnb.ca/oooo/publications /comm/1894_Publication_E.pdf

http://www.gnb.ca/cnb/news/edu/ 2004e0357ed.htm

http://www.gnb.ca//0000/qla_e.asp

http://www.learningforlife.ednet.ns.ca

http://www.learningforlife.ednet.ns.ca/ background.shtml

http://www.learningforlife.ednet.ca/ bascis_first.shtml

http://www.ayr.ednet.ns.ca

http://www.gov.ns.ca/news/printpage .aspid $=200050131007$

http://www.pei.literacy.ca http://www.ed.gov.nl.ca/edu/ literacy/lit.html

http://www.os.edu.gov.nf.ca/dsit/ pkg_dbutility.SLF_project?p_ project_id $=489$

http://www.os.edu.nl.ca/edu/ literacy/litplan.pdf

http://www.education.gov.yk.ca/ advanced/labour/literacyprograms. html

http://www.ece.gov.nt.ca/Publications

http://www.gov.nu.ca/ education/Arviat \%20Pictionary \% 20Site/index.html

Sections of this report provide a synopsis of information gathered through consultation with the following people and Internet sites:

Literacy Consultants:

Tina Conlon, Niagara Catholic District School Board

Joanne Folville, Halton Catholic District School Board

Kathy Scarth, Hamilton-Wentworth District School Board

Maureen Wills, Brant Haldimand Norfolk Catholic District School Board

Julia Beddoe, The Working Centre, Kitchener

Victoria Poe, 2 Lead Change, Guelph
Jennifer Cassidy, Amanda Dreyer, Julia Johnson, Heidi Lenz, Veronica Manning, Kelly

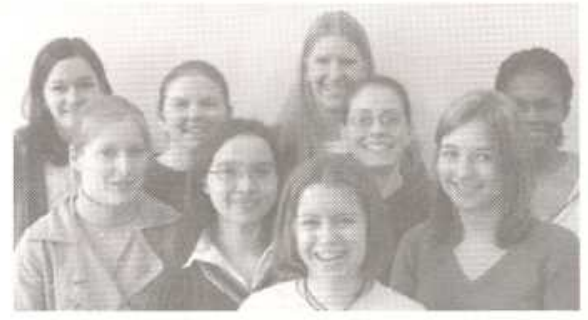

Nolan, Amelia O'Seasnain, Emily Phillips and Diana Spence are students enrolled in the Brock-Waterloo French Teaching Specialization, Pre-Service Program at the Hamilton Campus. They have studied and lived together for more than five years taking courses at the University of Waterloo and Brock University concurrently. They have travelled extensively, completed cooperative teaching assignments in France and or Quebec and are completely bilingual. This article was a result of a collaborative experience examining and discussing literacy initiatives. In June they will graduate with two degrees a Bachelor with honours degree from Waterloo and a Bachelor of Education from Brock University.

Teach one Reach One is the motto of the Canadian Laubach Literacy Initiative of Canada and is a member of Laubach International. This non profit organization trains volunteers to help Canadians learn to read and write. For more information about the successes of the Laubach reading and writing program and to become a member contact www.laubach.ca

\section{Reading is going to the Dogs}

A recent initiative by the Cape Breton, St. John's ambulance therapy Dog program is providing reluctant readers with a new incentive and motivation. It appears that dogs like to be read to and an Irish setter named Arthur loves books so much that he has pioneered a new approach that is gaining momentum and success. It seems that unlike humans, dogs listen and listen attentively regardless if the reader makes mistakes. Cape Breton school children love the program. So much so that more than 60 other puppies eager to listen to others learn how to read are listening to books and helping children turn on to books. Perhaps current intervention reading programs have been "barking up the wrong tree" and should get in touch with Arthur the canine book lover for advice. 